\title{
Nutrient Management in Indian Bean (Lablab purpureus L.) under South Gujarat Condition
}

\author{
B.M. Baldaniya ${ }^{1 *}$, V.M. Patel $^{2}$, L.B. Kalasariya ${ }^{3}$ and T.V. Reddy ${ }^{4}$ \\ ${ }^{1}$ Regional Research Station, Anand Agricultural University, Anand, Gujarat, India \\ ${ }^{2}$ Pulses and Castor Research Station, Navsari Agricultural University, Navsari, Gujarat; \\ ${ }^{3}$ Department of Agronomy, N.M. College of Agriculture Navsari Agricultural University, \\ Navsari, Gujarat, India \\ ${ }^{4}$ Department of Agronomy, College of Agriculture Kerala Agricultural University, \\ Vellanikkara, Thrissur, kerala, India \\ *Corresponding author
}

\begin{abstract}
A B S T R A C T
\section{Keywords}

Indian bean,

Nutrient

management,

Biocompost,

Growth and yield

attributes, Seed

yield, Economics

Article Info

Accepted:

20 February 2019

Available Online:

10 March 2019

A field experiment was conducted during rabi season of 2015-16 on vertisols of Navsari, Gujaratto study the Nutrient management in Indian bean (Lablab purpureus L.) under south Gujarat condition. Almost all the growth and yield attributes such as plant height at 60 DAS and at harvest, number of branches per plant at 60 DAS and at harvest, dry matter accumulation per plant at 60 DAS and at harvest, number of inflorescences per plant, number of pods per plant, number of seeds per pod, length of pod and 100 seed weight at harvest were recorded significantly higher with application of $125 \%$ RDF through inorganic fertilizer over $100 \%$ RDF. Similarly, seed (728kg/ha) and stover yield (1484 $\mathrm{kg} / \mathrm{ha}$ ) of crop were also noted significantly higher with application of $125 \% \mathrm{RDF}$ than $100 \%$ RDF. An application of $2 \mathrm{t} /$ ha biocompost resulted in significantly higher seed yield and stover yield $(727 \mathrm{~kg} / \mathrm{ha}$ and $1490 \mathrm{~kg} / \mathrm{ha}$, respectively) over other treatments because of significant enhancement in growth and yield attributes under the same treatment $(2 \mathrm{t} / \mathrm{ha}$ biocompost).Foliar application of $1 \%$ banana pseudostem enrich sap to Indian bean at 30 and 60 DAS was resulted in significantly higher growth and yield attributes over without foliar spray (control), ultimately resulted in significantly higher seed and stover yield of Indian bean as well as higher economic returns.
\end{abstract}

\section{Introduction}

Indian bean (Lablab purpureus L.) also known as field bean or dolichos bean, is grown throughout tropical regions of Asia, Africa and America. In India, it is grown as a field crop in Tamil Nadu, Andhra Pradesh, Karnataka, Madhya Pradesh and Maharashtra. The Indian bean belongs to the family Leguminosae and considered as nutritious vegetables as they contain high amount of vegetable protein, besides carbohydrates and 
vitamins. In south Gujarat, Indian bean is most important crop grown particularly in Navsari, Surat and Valsad districts. It is mostly grown during rabi season in field vacated by kharif crops like paddy. A new variety GNIB -21 found most promising for vegetable purpose due to it's short stature plants, early picking and short maturity. It became popular among the farmer of south Gujarat due to it's suitability as intercrop also. Now days, use of chemical fertilizer is increasing to boost up crop production. Simultaneously, cost of chemical fertilizer is increased constantly, besides these, only use of inorganic fertilizer is injurious to soil health and soil productivity. Integration of inorganic, organic and bio-fertilizer play vital role for enhancing crop productivity and sustaining soil fertility, this proves great promise for farmer. Thus the basic concept underlying the principles of integrated nutrient management is the maintenance and possible improvement in soil fertility for sustained crop productivity on long term basis (Harisudan et al., 2009). Foliar application of fertilizers for increasing and exploiting genetic potential of the crop is considered as an efficient and economic method of supplementing the nutrient requirement. Application of inorganic spray will also enhances play a pivotal role in increasing the seed yield in pulses (Chandrasekhar and Bangarusamy, 2003). Foliar application of major nutrients like NPK was found to be more advantageous than soil application and also avoiding the depletion of these nutrients in leaves, thereby resulting in to an increased photosynthetic rate, better nutrients translocation is credited with the advantage of quick and efficient utilization of nutrients, elimination of losses through leaching and fixation and helps in regulating the uptake of nutrients by plants (Manomani and Srimathi, 2009). A judicious combination of chemical fertilizer and organic fertilizer should be formulated for Indian bean variety GNIB-21 under south Gujarat condition, hence, the present study is proposed.

\section{Materials and Methods}

Field experiment was conducted on plot no. D-17 at College Farm, N.M. College of Agriculture, Navsari Agricultural University, Navsari, during rabi season of 2015-16. Navsari Agricultural University is geographically located at $20^{\circ} 57^{\prime} \mathrm{N}$ latitude and $72^{\circ} 54^{\prime} \mathrm{E}$ longitude with an altitude of 10 meters above the mean sea level. Navsari is located in south Gujarat heavy rainfall zone-I (Agro-ecological situation-III). The climate of this zone is typically sub-tropical, characterized by humid and warm monsoon with heavy rains, quite cold winter and fairly hot summer. The average annual rainfall of this tract is about $1440 \mathrm{~mm}$. The soil of experimental field was clayey in texture having medium to poor drainage, EC 0.36 $\mathrm{dS} / \mathrm{m}$ and soil $\mathrm{pH} 7.80$. The soil is medium in organic carbon $(0.53 \%)$, low in available nitrogen $(197.26 \mathrm{~kg} / \mathrm{ha})$, medium in available phosphorus $(30.93 \mathrm{~kg} / \mathrm{ha}$ ) and fairly rich in available potassium (369.80 $\mathrm{kg} / \mathrm{ha})$.Total twelve treatment combinations consisting of two levels of inorganic fertilizer viz., F1 (100\% RDF) and F2 (125\% RDF), three types of organic manure viz., O1 (2 t/ha FYM), O2 (2 t/ha Biocompost) and O3 (2 t/ha Vermicompost) and two levels of foliar spray viz., S1 (Without spray) and S2 (1\% Banana pseudostem enrich sap spray at 30 and 60 DAS) were evaluated in randomized block design with factorial concept with three replications. Indian bean variety GNIB-21 was used as a test crop and sown at a distance of $45 \mathrm{~cm} \times 20 \mathrm{~cm}$. The experimental plot was manure as per treatment with inorganic fertilizer and organic manure before sowing of crop. Required quantity of FYM, biocompost and vermicompost as well as inorganic fertilizer in the form of urea and DAP (Diammonium phosphate) were 
calculated and manually applied in opened furrows as per treatment before sowing. Gap filling and thinning were done when necessary and harvesting was done when crop was full matured. Irrigations, plant protection and other practices were followed as per recommendation for this region for healthy crop growth. Economics of treatments were computed on the basis of prevailing market price of inputs and outputs in Indian rupees under each treatment. The total cost of cultivation was calculated on the basis of different operations performed and materials used for raising crop. Statistical analysis of the data as per the standard analysis of variance technique for the experimental design and treatment means were compared at $\mathrm{P}=0.05$ level of probability using t-test and calculating $\mathrm{CD}$ value.

\section{Results and Discussion}

\section{Growth characters}

Inorganic fertilizer, organic manure and foliar spray had significant influenced on growth characters (Table 1). The various growth attributes like plant height, number of branches per plant and dry matter accumulation per plant recorded at 60 DAS and at harvest were significantly higher with application of $125 \% \mathrm{RDF}$ as compared to application of $100 \%$ RDF. Zahida et al., (2016) also reported beneficial effect of $125 \%$ RDF in French bean for growth attributes. Further data presented in Table 1 revealed that significantly higher plant height, number of branches per plant as well as dry matter accumulation per plant at 60 DAS and at harvest were recorded under application of 2 t/ha biocompost being at par with application of $2 \mathrm{t} /$ ha vermicompost over application of 2 t/ha FYM. The increases in growth parameters under these treatments might be due to higher nutrients contents than FYM, improved the nutrient status of soil. Addition of organic matter in soil not only improved the physical properties of soil but also enhance the microbial activity which reflected in the possible increases of nutrient status of soil ultimately it improved the growth of crop. These results are in close conformity with the findings of Chaudhari et al., (2016) and Patel et al., (2016) in greengram. Foliar spray of $1 \%$ banana pseudostem enrich sap at 30 and 60 DAS was resulted in the highest plant height, number of branches per plant and dry matter accumulation per plant at 60 DAS and at harvest over without spray. The foliar spray of organic supplies the adequate amount of nutrients to plant at peak growth stage of crop. Further foliar application of organic facilitate the easily absorption of nutrient resulted in improvement of plant growth. Results are in accordance with that of Patil and Gunjal (2011) in green gram and Patil et al., (2012) in chickpea.

\section{Yield attributes and yield}

The various yields attributes like number of inflorescences per plant, number of pods per plant, number of seeds per pod, length of pod, and 100 seed weight as well as seed yield and stover yield were influenced significantly due to application of various levels of inorganic fertilizer, types of organic manures and levels of foliar spray (Table 2). The highest number of inflorescences per plant, number of pods per plant, number of seeds per pod, length of pod and 100 seed weight were noted under the application of $125 \%$ RDF than $100 \%$ RDF. Similarly, an application of $125 \% \mathrm{RDF}$ produced significantly higher seed (728.78 $\mathrm{kg} / \mathrm{ha}$ ) and stover yield (1484.15 kg/ha) which was to the tune of 14.86 and 13.43 per cent higher, respectively than that of due to application of $100 \%$ RDF. The marked increases in seed and stover yields might be due to beneficial effect of higher level of RDF on various growths and yield attributes. 
Table.1 Growth attributes of Indian bean as influenced by nutrient management practices

\begin{tabular}{|c|c|c|c|c|c|c|}
\hline \multirow[t]{2}{*}{ Treatments } & \multicolumn{2}{|c|}{ Plant height (cm) } & \multicolumn{2}{|c|}{$\begin{array}{c}\text { Number of branches per } \\
\text { plant }\end{array}$} & \multicolumn{2}{|c|}{$\begin{array}{c}\text { Dry matter accumulation } \\
\text { per plant (g) }\end{array}$} \\
\hline & at 60 DAS & at harvest & at $60 \mathrm{DAS}$ & at harvest & at 60 DAS & at harvest \\
\hline \multicolumn{7}{|l|}{ Inorganic fertilizer $(F)$} \\
\hline $\mathrm{F}_{1}-100 \% \mathrm{RDF}$ & 35.93 & 41.52 & 5.06 & 6.27 & 7.42 & 13.25 \\
\hline $\mathrm{F}_{2}-125 \% \mathrm{RDF}$ & 39.72 & 46.27 & 6.53 & 8.44 & 8.48 & 15.43 \\
\hline S.Em. \pm & 0.78 & 0.86 & 0.16 & 0.23 & 0.17 & 0.20 \\
\hline C.D. $(P=0.05)$ & 2.30 & 2.52 & 0.49 & 0.66 & 0.51 & 0.61 \\
\hline \multicolumn{7}{|l|}{ Organic manures $(\mathbf{O})$} \\
\hline$O_{1}-2 t / h a ~ F Y M$ & 35.13 & 40.69 & 5.07 & 6.53 & 7.05 & 13.42 \\
\hline $\mathrm{O}_{2^{-}}$2t/ha Biocompost & 40.11 & 47.00 & 6.48 & 8.12 & 8.81 & 15.22 \\
\hline $\mathrm{O}_{3}$ - 2t/ha Vermicompost & 38.23 & 44.07 & 5.83 & 7.42 & 7.98 & 14.39 \\
\hline S.Em. \pm & 0.96 & 1.05 & 0.20 & 0.28 & 0.21 & 0.25 \\
\hline C.D. $(P=0.05)$ & 2.81 & 3.09 & 0.60 & 0.81 & 0.63 & 0.74 \\
\hline \multicolumn{7}{|l|}{ Foliar spray (S) } \\
\hline$S_{1}$ - Without spray & 35.70 & 41.64 & 5.26 & 6.93 & 7.61 & 13.94 \\
\hline $\begin{array}{l}\mathrm{S}_{2}-1 \% \text { Banana pseudo- } \\
\text { stemenrich sap spray }\end{array}$ & 39.96 & 46.20 & 6.32 & 7.78 & 8.29 & 14.74 \\
\hline S.Em. \pm & 0.78 & 0.86 & 0.16 & 0.22 & 0.17 & 0.20 \\
\hline C.D. $(P=0.05)$ & 2.30 & 2.53 & 0.48 & 0.66 & 0.51 & 0.61 \\
\hline Interaction & NS & NS & NS & NS & NS & NS \\
\hline $\mathrm{CV} \%$ & 8.79 & 8.32 & 12.14 & 12.97 & 9.32 & 6.11 \\
\hline
\end{tabular}


Table.2 Yield attributes and yields of Indian bean as influenced by nutrient management practices

\begin{tabular}{|c|c|c|c|c|c|c|c|}
\hline Treatments & $\begin{array}{c}\text { Number of } \\
\text { inflorescences } \\
\text { per plant }\end{array}$ & $\begin{array}{c}\text { Number of } \\
\text { Pods } \\
\text { per plant }\end{array}$ & $\begin{array}{c}\text { Number of } \\
\text { seeds } \\
\text { per pod }\end{array}$ & $\begin{array}{l}\text { Length } \\
\text { of pod } \\
(\mathrm{cm})\end{array}$ & $\begin{array}{l}100 \text { seed } \\
\text { Weight } \\
\text { (g) }\end{array}$ & $\begin{array}{c}\text { Seed } \\
\text { Yield } \\
\text { (kg/ha) }\end{array}$ & $\begin{array}{c}\text { Stover } \\
\text { Yield } \\
\text { (kg/ha) }\end{array}$ \\
\hline \multicolumn{8}{|l|}{ Inorganic fertilizer $(F)$} \\
\hline$F_{1}-100 \% R D F$ & 6.81 & 23.22 & 3.10 & 3.8 & 13.16 & 634 & 1308 \\
\hline $\mathrm{F}_{2}-125 \% \mathrm{RDF}$ & 9.24 & 26.11 & 3.93 & 4.1 & 14.60 & 728 & 1484 \\
\hline S.Em. \pm & 0.21 & 0.51 & 0.08 & 0.08 & 0.23 & 17.27 & 31.66 \\
\hline C.D. $(P=0.05)$ & 0.61 & 1.50 & 0.24 & 0.24 & 0.68 & 50.67 & 92.87 \\
\hline \multicolumn{8}{|l|}{ Organic manures (O) } \\
\hline$O_{1}-2 t / h a ~ F Y M$ & 7.45 & 21.58 & 2.81 & 3.8 & 12.66 & 620 & 1288 \\
\hline $\mathrm{O}_{2-}$ 2t/ha Biocompost & 8.35 & 26.75 & 4.16 & 4.4 & 14.77 & 727 & 1490 \\
\hline $\mathrm{O}_{3^{-}}$2t/ha Vermicompost & 8.28 & 25.66 & 3.58 & 3.8 & 14.23 & 697 & 1409 \\
\hline S.Em. \pm & 0.25 & 0.63 & 0.10 & 0.09 & 0.28 & 21.16 & 38.77 \\
\hline C.D. $(P=0.05)$ & 0.74 & 1.83 & 0.30 & 0.28 & 0.84 & 62.06 & 113.74 \\
\hline \multicolumn{8}{|l|}{ Foliar spray (S) } \\
\hline$S_{1}$ - Without spray & 7.70 & 23.28 & 3.19 & 3.8 & 13.33 & 641 & 1328 \\
\hline $\begin{array}{l}\mathrm{S}_{2} \text { - } 1 \% \text { Banana pseudo- } \\
\text { stemenrich sap spray }\end{array}$ & 8.35 & 26.06 & 3.85 & 4.2 & 14.43 & 721 & 1464 \\
\hline S.Em. \pm & 0.21 & 0.51 & 0.08 & 0.08 & 0.23 & 17.27 & 31.66 \\
\hline C.D. $(P=0.05)$ & 0.61 & 1.50 & 0.24 & 0.24 & 0.68 & 50.67 & 92.87 \\
\hline Interaction & NS & NS & NS & NS & NS & NS & NS \\
\hline CV \% & 10.94 & 8.78 & 10.03 & 8.46 & 7.11 & 10.25 & 9.62 \\
\hline
\end{tabular}


Table.3 Economics of Indian bean as influenced by nutrient management practices

\begin{tabular}{|c|c|c|c|c|c|c|}
\hline Treatments & $\begin{array}{l}\text { Seed yield } \\
\text { (kg/ha) }\end{array}$ & $\begin{array}{l}\text { Stover yield } \\
\text { (kg/ha) }\end{array}$ & $\begin{array}{c}\text { Gross } \\
\text { realization } \\
\text { (Rs./ha) }\end{array}$ & $\begin{array}{c}\text { Cost of } \\
\text { production } \\
\text { (Rs./ha) }\end{array}$ & $\begin{array}{l}\text { Net realization } \\
\text { (Rs./ha) }\end{array}$ & BCR \\
\hline \multicolumn{7}{|l|}{ Inorganic fertilizer $(F)$} \\
\hline$F_{1}-100 \%$ RDF & 634 & 1308 & 43955 & 30301 & 13654 & 1.45 \\
\hline $\mathrm{F}_{2}-125 \% \mathrm{RDF}$ & 728 & 1484 & 50405 & 30843 & 19562 & 1.63 \\
\hline \multicolumn{7}{|l|}{ Organic manures $(\mathbf{O})$} \\
\hline$O_{1}-2 t / h a ~ F Y M$ & 620 & 1288 & 43020 & 34107 & 8913 & 1.26 \\
\hline $\mathrm{O}_{2^{-}}$2t/ha Biocompost & 727 & 1490 & 50345 & 29107 & 20638 & 1.69 \\
\hline $\mathrm{O}_{3^{-}}$2t/ha Vermicompost & 697 & 1409 & 48176 & 39107 & 9069 & 1.23 \\
\hline \multicolumn{7}{|l|}{ Foliar spray (S) } \\
\hline$S_{1}$ - without spray & 641 & 1328 & 44437 & 28107 & 16330 & 1.58 \\
\hline $\begin{array}{l}S_{2}-1 \% \text { Bananapseudostem } \\
\text { enrich sap spray }\end{array}$ & 721 & 1464 & 49904 & 30607 & 19297 & 1.63 \\
\hline
\end{tabular}


These findings are in agreement with Arbad et al., (2014) in soybean and Zahida et al., (2016) in French bean. Various yield attributes viz., number of inflorescences per plant, number of pods per plant, number of seeds per pod, length of pod and 100 seed weight were recorded significantly higher with application of 2 t/ha biocompost, but it remained at par with application of $2 \mathrm{t} / \mathrm{ha}$ vermicompost for number of inflorescences per plant, number of pods per plant and number of seeds per pod over application of 2 t/ha FYM. An application of 2 t/ha biocompost resulted in significantly higher seed yield $(727.30 \mathrm{~kg} / \mathrm{ha})$ and stover yield $(1490.55 \mathrm{~kg} / \mathrm{ha})$, but it remained statistically at par with application of $2 \mathrm{t} / \mathrm{ha}$ vermicompost over application of $2 \mathrm{t} / \mathrm{ha}$ FYM. This might be due to the favourable effect of biocompost on chemical, physical and biological properties of soil leads to easy availability of nutrients might have reflected in higher growth and yield attributes which ultimately resulted in higher yield of Indian bean. These results are in close vicinity with the findings of Chaudhari et al., (2016), Patel et al., (2016) and Sindhi et al., (2016) in greengram. The highest number of inflorescences per plant, number of pods per plant, number of seeds per pod, length of pod and 100 seed weight at harvest were noted under the treatment of $1 \%$ banana pseudostem enrich sap spray at 30 and 60 DAS over without spray. Foliar application of $1 \%$ banana pseudostem enrich sap resulted insignificantly higher seed yield (721.91 $\mathrm{kg} / \mathrm{ha})$ and stover yield (1464.31 kg/ha) over without spray (S1). This might be due to the favourable effect of treatment on plant because of easy availability of nutrients might have reflected in higher growth parameter and yield attributes ultimately resulted in higher yields. These results are in close vicinity with the findings of Patil et al., (2012) in chickpea and Singhal et al., (2015) in cowpea. Interaction effects between different levels of inorganic fertilizer, various type of organic manures and levels of foliar spray of organic were found non-significant for all characters of Indian bean crop studied during course of investigation.

\section{Economics}

Economics (Table 3) showed that Maximum gross realization (Rs. 50405/ha), net realization (Rs. 19562/ha) and BCR (1.63) were obtained with the application of $125 \%$ RDF through inorganic fertilizer over $100 \%$ RDF. Increase in the gross and net realization might be due to increase in the seed yield under the same treatments. This is in accordance with the findings of Zahida $e t$ al., (2016) in French bean. Similarly, maximum gross realization of Rs. 50345/ha, net realization of Rs. 20638/ha and BCR of 1.69 were secured with application of $2 \mathrm{t} / \mathrm{ha}$ biocompost over other treatments. Foliar application of $1 \%$ banana pseudostem enriched sap at 30 and 60 DAS was resulted in maximum gross realization of Rs. 49904/ha, net realization of Rs. 19297/ha with BCR of 1.63 over without spray.

It is concluded that an application of $125 \%$ RDF through inorganic fertilizer and 2 t/ha biocompost organic manure at the time of sowing and foliar application of $1 \%$ banana pseudostem enrich sap at 30 and 60 DAS were resulted in better crop growth and profitable yield of Indian bean grown under of south Gujarat condition.

\section{References}

Arbad, B. K., Ismail, S. and Dhawan, A. S. 2014. Influence of long term use of farm yard manure and inorganic fertilizer on grain yield and nutrient availability in vertisols under soybeansafflower sequence cropping. Legume Research,37(6):600-606.

Chandrasekhar, C. N. and Bangarusamy, U. 
2003. Maximizing the yield of mungbean by foliar application of growth regulating chemicals and nutrients. Madras Agricultural Journal, 90(1-3): 142-145.

Chaudhari, S. N., Thanki, J. D., Chaudhari, V. D. and Verma, C.2016. Yield attributes, yield and quality of black greengram (Vign aradiata L.) as influenced by organic manures, biofertilizer and phosphorus fertilization. The Bioscan, 11(1):431-433.

Harisudan, C., Latha, K. R., Subbian, P., Vaidyanathan, R. and Manivannan, V. 2009. Nutrient management for rainfed pulses. Agricultural Review, 30(3): 224228.

Manonmani, V. and Srimathi, P. 2009. Influence of mother crop nutrition on seed and quality of blackgram. Madras Agricultural Journal, 96(16): 125-128

Patel, A. R., Patel, D. D., Patel, T. U. and Patel, H. M. 2016. Nutrient management in summer greengram(Vigna radiate L.). International Journal of Applied and Pure Science and Agriculture,2(2):133142.

Patil, S. M. and Gunjal, B. S. 2011. Effect of potassium and foliar spray of cow urine on growth and yield of greengram [Vigna radiate (L.) Wilczok]. International Journal of Forestry and
Crop Improvement, 2(1):102-103.

Patil, S. V., Halikatti, S. I., Hiremath, S. M.; Babalad, H. B., Sreenivasa, M. N., Hebsur, N. S. and Somanagouda, G. 2012. Effect of organics on growth and yield of chickpea (Cicer arietinum L.) in vertisols. Karnataka Journal of Agriculture Science, 25 (3):326-331.

Sindhi, S. J., Thanki, J. D., Mansuri, R. N. and Desai, L. J.2016. Nutrient content as well as uptake of maize and greengram as affected by integrated nutrient management in maizegreengram cropping sequence under south Gujarat condition. International Journal of Agriculture Sciences, 8(53): 2626-2630.

Singhal, V. K., Patel, G. G., Patel, D. H., Kumar, U. and Saini, L. K. 2015. Effect of foliar application of water soluble fertilizers on growth, yield and economics of vegetable cowpea production. The Ecoscan, 7:79-83.

Zahida, R., Dar, S. B., Mudasir, R. and Inamullah, S. 2016. Productivity and quality of french bean (Phaseolus vulgaris L.) as influenced by integrating various sources of nutrients under temperate conditions of Kashmir. International Journal of Food, Agriculture and Veterinary Sciences, 6(1):15-20.

\section{How to cite this article:}

Baldaniya, B.M., V.M. Patel, L.B. Kalasariya and Reddy, T.V. 2019. Nutrient Management in Indian Bean (Lablab purpureus L.) under South Gujarat Condition. Int.J.Curr.Microbiol.App.Sci. 8(03): 2443-2450. doi: https://doi.org/10.20546/ijcmas.2019.803.288 